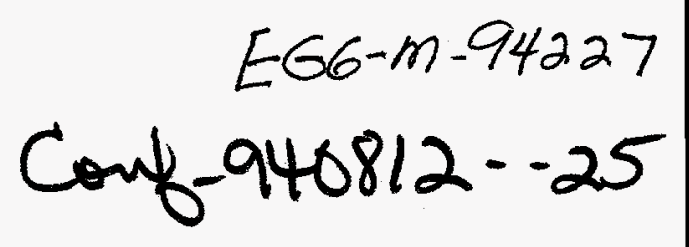

\title{
A SOLAR POWERED DISTILLATION PLANT AND PUMP STATION FOR USE IN OCEAN SIDE DESERT AREAS
}

Dr. John A. Dearien, Mechanical Engineering, Idaho National Engineering Laboratory, Idaho Falls, Idaho

Dr. Stephen J. Priebe, Energy Programs, Idaho National Engineering Laboratory, Idaho Falls, Idaho

\begin{abstract}
$\underline{\text { Abstract }}$
There are thousands of miles of ocean shoreline which could sustain a productive human existence if sufficient fresh water were available for human consumption and for irrigation of crops. While solar stills can be built to produce fresh water at or close to sea level, raising water to a height sufficient to irrigate crops, even with minimum water usage crops, requires a significant amount of energy. This paper describes a "no-external power" process by which seawater can be purified and raised to a height above sea level sufficient to carry on a productive living in certain areas of the world. This device, the Solar Evaporation and Pumping System (SEAPS) is described as to function and areas of use.
\end{abstract}

\section{Applicable Locations For System}

The basic requirements for a site on which one might apply the SEAPS are:

1. Access to seawater

2. Low lying area next to shore of at least $10,000 \mathrm{ft}^{2}$.

3. High solar insolation

4. Elevated land adjacent to shore which can grow irrigated crops.
A typical profile for an ideal location would be as illustrated in Figure 1.

\section{Operation of SEAPS}

SEAPS operates on the principal of low temperature, partial vacuum distillation of water with the subsequent pumping of the low pressure steam to heights much greater than would be obtainable in a single phase, liquid siphon system. Energy to power the system is derived from solar energy collected in a solar pond. The hot water formed in the solar pond is then used, either directly in the vacuum distillation process or as a heat source to a secondary system. The components and layout of the system are illustrated in Figure 1.

A solar pond is constructed in the low lying area adjacent to the sea with a small access channel to maintain water level in the pond. The system, operating under the steady state conditions illustrated in Figure 1, has a partial vacuum in the steam line and the upper portion of the evaporation module. This vacuum is maintained by the hydraulic head difference between the water outlet pool level and the condensate tank water level. Under the influence of the partial vacuum at the top of the evaporation module, water is

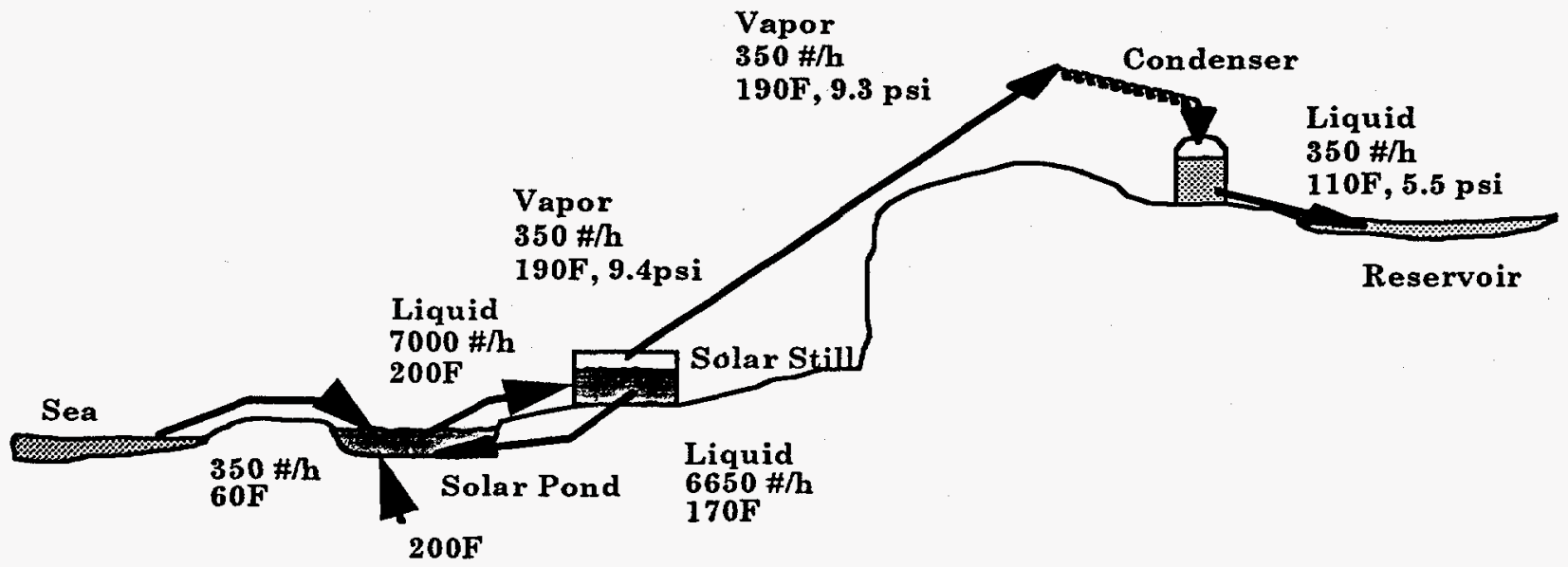

Figure 1. Solar Evaporation and Pumping System (SEAPS) 
drawn from the solar pond through the inlet pipe into the evaporation module. As the water flows upward in the evaporation module, its pressure is decreased until it flash evaporates. The steam rises into the steam dome of the evaporation module and into the steam line. The unflashed liquid, slightly cooled and increased in salt content, sinks in the evaporator module toward the return pipe where it is returned to the bottom of the solar pond.

The low pressure, low density steam rises to the top of the system where it is sent, downward, through a condenser and into a condensate collection tank with at least 30 feet of vertical liquid storage above the outlet nozzle. Water is extracted from the condensate tank into a water outlet pool at a rate which is in balance with the evaporation process in the evaporator module.

\section{Start-Up of System}

It is necessary to liquid fill the entire system in order to remove the non-condensable gases and establish the partial vacuum necessary for system operation. Valves on the upper water outlet (closed), top of the steam line (open), and on the evaporator inlet \& outlet lines (closed) allow the system to be filled with liquid with a pump attached to the evaporator module inlet line. A small gasoline powered pump, or even a manual pump, can be used for the initial fill. When the system is liquid full, the valve at the top of the steam line is closed and the valves of the evaporator module are opened. The water in the steam line will vaporize, lowering the liquid level in the lower part of the system to a level approximately 30 feet above solar pond level. The water outlet valve is then opened and the water in the condensate collection tank will fall to a level approximately 30 feet above the water outlet pool level.

Internal baffling of the evaporation module is designed such that residue water from the flashing process, cooler and with a higher salt content, is directed toward the evaporator module outlet pipe. The density gradient within the evaporator module will establish a thermal siphon which draws warm water from the solar pond up through the inlet pipe and discharges cooled water out through the return pipe. The inlet pipe is adjustable in elevation to draw water from the hottest part of the pool and the return pipe is positioned to return the higher density effluent from the evaporator to the bottom of the pool.

As the system operates over time, the higher salinity of the return flow will increase the average salinity of the pool. With a small amount of the fresh water generated, a cover layer of fresh water is established and maintained over the solar pond, increasing the thermal efficiency of the pond ${ }^{(1)}$.

As the solar pond salinity increases over time, if not controlled, the solar pond will reach a salinity which would result in precipitation of salt crystals and affect system operation. A salinity control siphon is installed from the solar pond, over the protective bank, to the sea. The higher density of the solar pond fluid and the cooling provided by the sea on the outlet leg provides the driving force for the salinity control siphon. The pond outflow rate is controlled by the length and discharge depth of the outlet leg.

\section{Operating System Example}

The following example provides specific state points for a representative system. The system is designed to supply 1000 gallons per day to an elevation 100 feet above mean sea level. The total area required for the solar pond is a function of the solar insolation at a particular site. Assuming a rate of $50 \mathrm{Btu} / \mathrm{hr}-\mathrm{ft} 2$, averaged over 24 hours, gives an area of about 7800 $\mathrm{ft} 2$. The depth of the solar pond would be about 6 to 8 $\mathrm{ft}$, giving a total quantity of water of about 0.5 million gallons. This provides a sufficient heat sink that even when operating at night, the solar pond temperature will only decrease about $0.1 \mathrm{~F} / \mathrm{hr}$. The state points for this system are included in Figure 1.

\section{Operational Dynamics of System}

The SEAPS must operate in a broad range of controlling parameters and must be stable under all of the conditions. The primary variables in the operation of SEAPS are (1) solar pond temperature, (2) evaporator module steam dome temperature, and (3) condensate tank liquid level.

The water levels in the evaporator module and the condensate tank are a direct function of the steam line vacuum and the steam line vacuum is a direct function of the vapor pressure and temperature in the evaporator module. As the temperature rises and falls in the solar pond inlet to the evaporator, the levels in both the evaporator module and the condensate tank wil vary. The vertical "working" heights of these two components are sized such that desired operation is maintained over the range of expected temperature variations. Figure 2 shows the height of the still above the solar pond, and the fresh water production rate as a function of the temperature in the still. 


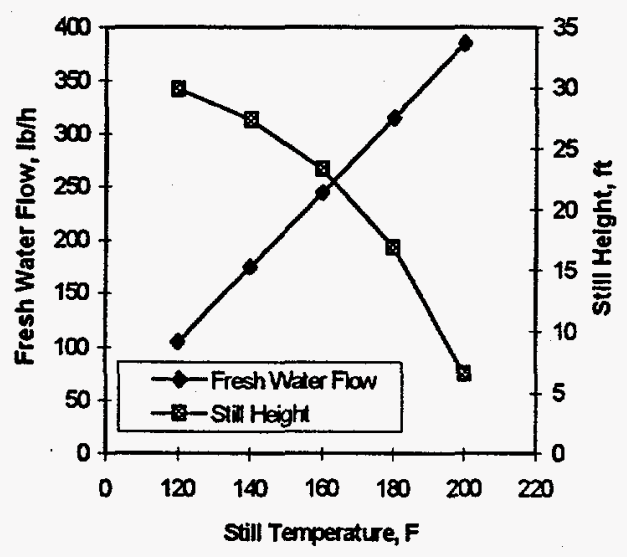

Figure 2. Water Flow vs Still temperature

A start up transient occurs when the system is first brought on line. It is expected that sufficient time will have elapsed in the construction process for the solar pond to have reached a temperature of at least $120 \mathrm{~F}$. When the system is started (see System Start-Up), the evaporator module will be operating at $120 \mathrm{~F}$ and normal seawater salinity levels. Production rates of the system at this point is 100 pounds/hr of fresh water. This rate, with the fresh water volume being replaced by seawater, represents an addition of 3 pounds of salt per hour to the pond. As the pond increases in salinity, a salinity gradient is established by returning the evaporator brine to the bottom of the pond and a portion of the generated fresh water to the top of the pond. As the salinity gradient and insulating fresh water layer at the surface become established, the temperature of the pond will increase, as well as the fresh water production rate of the system. At optimum operating conditions, solar pond temperatures are expected to be close to $200 \mathrm{~F}^{(2)}$ with a fresh water production rate of 350 pounds $/ \mathrm{hr}$ and a salt addition rate to the pond of 10 pounds $/ \mathrm{hr}$.

When the salinity level in the pond reaches a point for maximum fresh water production rate (unknown at this time), the salinity control siphon is started to maintain optimum salinity level. Establishment of siphon flow rates to accomplish this control will be an iterative process and will probably require periodic adjustment.

\section{Maintenance and Control}

The only short term maintenance expected for the system is the periodic removal of non-condensables from the system. The valve at the high point of the system (just above the condenser zone) is connected to a hand operated vacuum pump and the pump is used to periodically extract the non-condensables from the system. The frequency with which this is required will depend on the dissolved gas in the particular location and acceptable degradation in system performance prior to gas maintenance. It is expected that the dissolved gas, and therefore generation of noncondensables in the system, will decrease over time due to the increasing bulk temperature of the pond and the near closed cycle nature of the transfer of pond water through the system.

Long term testing of the system will be required before other potential maintenance problems are defined - such as build up of precipitates.

\section{Materials and Construction}

The system is designed to be constructed and operated in a remote and developing area, thus the components are selected on the basis of being inexpensive, durable, light, and easily fabricated. The system is designed to be constructed from off-the-shelf plastic pipe. The example problem in this paper would use 4 inch pipe in transfer lines, 12-18 inch pipe in the evaporator module, and $0.5-1.0$ inch pipe in the condenser zone. The pipes have a wall thickness sufficient to support a $-15 \mathrm{psi}$ internal vacuum without collapse.

The solar pond must be excavated to a depth of approximately 8 feet below mean sea level. Due to the fact that the solar pond surface is at mean seal level, sealing requirements for the pond should be minimal. Very porous soils and large tidal variations could adversely affect some sites.

The evaporator inlet line, evaporator module, and the steam line should be insulated for system thermal efficiency, but the steam line needs to be especially well insulated for system operation. Any condensation in the rising steam line will reduce the fresh water output of the system since the condensate will flow back into the evaporator module.

\section{Areas of Application}

The SEAPS can be applied in any coastal area with solar and geological conditions favorable to construction and operation of a solar pond. Soil conditions favorable to the growing of crops, with the low water use techniques pioneered by the Israeli's, 
should be available in the vicinity. This system could be used in areas of the world where a gradual buildup of population is possible, with a later application of more energy intensive water production processes when the population and requirements would support such an advanced system.

\section{Summary}

A system has been described which offers the possibility of producing life sustaining volumes of fresh water from sea water and pumping this water for agricultural use. The system is most applicable in developing areas or areas where sufficient power is not available for the sustained pumping of water for human and agricultural uses.

Testing of the system under a variety of environmental conditions is needed to establish optimum component sizes and operating procedures.

The system offers the potential of an inexpensive, simple, easily maintained device for supplying much needed water to many developing areas of the world.

\section{$\underline{\text { References }}$}

1. "And Now It Is Pond Power", Time Magazine, February 25, 1980, pp 39

2. Munson, Richard, "Israel's Solar Ponds Grow Larger", Environment, Volume 26, No. 1, January/February 1984, pp 41-42.

\section{Acknowledgement}

This work performed for the US Department of Energy, Assistance Secretary for Energy Efficiency and Renewable Energy. Under DOE contract number DEAC07-76ID01570.

\section{DISCLAIMER}

This report was prepared as an account of work sponsored by an agency of the United States Government. Neither the United States Gnvernment nor any agency thereof, nor any of their employees, makes any warranty, express or implied, or assumes any legal liability or responsibility for the accuracy, completeness, or usefulness of any information, apparatus, product, or process disclosed, or represents that its use would not infringe privately owned rights. Reference herein to any specific commercial product, process, or service by trade name, trademark, manufacturer, or otherwise does not necessarily constitute or imply its endorsement, recommendation, or favoring by the United States Government or any agency thereof. The views and opinions of authors expressed herein do not necessarily state or reflect those of the United States Government or any agency thereof. 


\section{DISCLAIMER}

Portions of this document may be illegible in electronic image products. Images are produced from the best available original document. 